Please do not remove this page

RMIT

UNIVERSITY

\title{
Australian construction supervisors' response to occupational health and safety
}

Cooke, Tracy; Lingard, Helen; Blismas, Nick

https://researchrepository.rmit.edu.au/esploro/outputs/9921859316301341/filesAndLinks?institution=61RMIT_INST\&index=null

Cooke, T., Lingard, H., \& Blismas, N. (2013). Australian construction supervisors' response to occupational health and safety. Proceedings of the Institution of Civil Engineers: Management, Procurement and Law, 166(6), 287-296. https://doi.org/10.1680/mpal.12.00012

Document Version: Published Version

Published Version: https://doi.org/10.1680/mpal.12.00012

Repository homepage: https://researchrepository.rmit.edu.au

(C) ICE Publishing

Downloaded On 2023/04/27 00:30:32 +1000

Please do not remove this page 
Thank you for downloading this document from the RMIT Research Repository.

The RMIT Research Repository is an open access database showcasing the research outputs of RMIT University researchers.

RMIT Research Repository: http://researchbank.rmit.edu.au/

\section{Citation:}

Cooke, T, Lingard, H and Blismas, N 2013, 'Australian construction supervisors' response to occupational health and safety', Proceedings of the Institution of Civil Engineers:

Management, Procurement and Law, vol. 166, no. 6, pp. 287-296.

See this record in the RMIT Research Repository at:

http://researchbank.rmit.edu.au/view/rmit:22641

Version: Published Version

Copyright Statement: (C) ICE Publishing

Link to Published Version:

http://dx.doi.org/10.1680/mpal.12.00012 
Management, Procurement and Law Volume 166 Issue MP6

Australian construction supervisors' response to occupational health and safety

Cooke, Lingard and Blismas

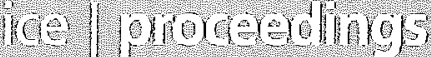

Proceedings of the Institution of Civil Engineers Maragernent, Procurement and Law 166

December 2013 lssue MP6

Pages 287.296 http: /dx dol org/ $0.1680 / \mathrm{mpal} / 1200012$

Paper 1200012

Received $02 / 05 / 2012$

Published online $16 / 09 / 2013$

Keywords: heallh \& safety/safety \& hazards

\section{Australian construction supervisors" response to occupational lhealth and safety}

\section{Tracy Cooke}

Research Fellow, RMIT University, Melbourne, Australia Helen Lingard

Professor, RMIT University, Melbourne, Australia
Nick Blismas

Associate Professor, RMIT University, Melbourne, Australia

A survey of Australian construction workers was conducted within three different organisations. The purpose of the survey was to determine whether members of workgroups within the construction industry develop unique and group-specific safety climates. The existence of group safety climate was ascertained by the degree of consensus between members of the same workgroup about their supervisors' response to safety within the organisation and the extent to which these perceptions varied between different workgroups within the same organisation. The research also evaluated the extent to which group-level safety climates were statistically linked to the injury/incident performance of workgroups in the three organisations. Although limited by the reliance on macro-incident data as the measure of workgroup safety performance, workers' perceptions of supervisors' safety expectations were inversely correlated with injury/incident rate in one organisation. The results provide much needed empirical evidence revealing the important role played by supervisors in defining the workgroup safety climates. Given that supervisors are a critical conduit through which organisational safety goals are articulated and achieved, the results indicate that the safety responses of first-level supervisors are likely to be just as important as, if not more so, than the actions of top management in construction organisations.

\section{Introduction}

\subsection{Safety climate}

In recent years a great deal of research has focused upon the concept of safety climate. Neal and Griffin (2006: pp. 946-947) define safety climate as 'individual perceptions of the policies, procedures and practices relating to safety in the workplace.' A large volume of empirical research has demonstrated a significant link between organisational safety climates and occupational health and safety (OHS) performance (Clarke, 2006). Safety climate is believed to shape the safety-related behaviour of people within organisations to the extent that it relates to expectations about how organisations value and reward safety (Zohar and Luria, 2005).

Previous research in the construction context has confirmed the link between safety climate and safety performance (Poussette et al., 2008; Siu et al., 2004; Zhou et al., 2008).

\subsection{Safety climate as a multi-level concept}

The majority of safety climate studies have focused on the organisation as the unit of analysis. It is increasingly recognised that focusing upon the organisation as the unit of analysis in safety climate is not sufficient. Zohar (2000) suggests that in large and complex organisations workgroups are likely to develop distinctly different safety climates, based upon workers localised experience of safety in practice. Thus, according to Zohar, two levels of safety climate exist: (a) that relating to perceptions of formal organisation-wide policies and procedures established by top management; and $(b)$ that relating to experiences of safety practices associated with the implementation of company policies and procedures within workgroups. The existence of group level safety climates has been used to explain significant variation in the safety performance of subunits within the same organisation. The development of distinct workgroup level safety climates has also been demonstrated within construction organisations (Lingard et al., 2009).

Failure to adequately specify the organisational level (or unit of analysis) in safety climate research has characterised some safety climate research in the construction context. Confounding organisational and workgroup level safety climate dimensions is likely to mask important between-group differences in safety climate perceptions. This is undesirable because between-group variation provides a good theoretical explanation for why workgroups within the same organisation can demonstrate consistently different levels of safety performance, even when they are exposed to the same workplace hazards and safety risks. 


\subsection{The role of supervisors}

Zohar (2000) suggests that the prevailing workgroup safety climate relates to patterns of supervisory safety practices. Consistent with this, Johnson (2007) revealed that perceptions of supervisors' safety actions predicted safety behaviour and the occurrence of incidents in the manufacturing sector. Arguably, perceptions of supervisors' safety responses should be a stronger predictor of safety performance than facets of the organisation level safety climate because most workers have little contact with senior management and are more likely to be influenced on a day-to-day basis by interactions with their supervisors.

Research suggests that supervisory practices play a key role in shaping workers' understanding of what is expected of them, by communicating the priority of safety in the workgroup or the importance of acting safely in a particular job. First-line supervisors are typically positioned at the intersection between management and the workforce and, as such, their actions are likely to influence the way in which workers interpret top managements' expectations. They act as a conduit between management and workers and monitor compliance with management's directives and provide managers with information about workers' compliance or negligence with regard to OHS (Niskanen, 1994). Supervisors provide important feedback to workers concerning the appropriateness of their behaviour. Supervisors' behaviour and expression of views will have considerable influence on the development of workers' beliefs about management policies and priorities. Leather (1987) points out that intentions which are communicated by supervisors as what management 'really wants' is not always consistent with the contents of formal policy statements or plans. The influence of supervisory practices was considerably greater than that of organisational factors, such as top management commitment or the appointment of a full-time company safety professional.

\section{Aim}

This research aimed to examine the role of supervisors in shaping group-level safety climates in the Australian construction context. Specifically, the following research objectives were identified.

(a) To analyse whether unique and distinct group-level safety climates exist within the Australian construction industry.

(b) If found to exist, to then examine the relationship between group level safety climates and the safety performance of workgroups in the Australian construction industry.

\section{Research methods}

\subsection{Data collection}

Group safety climate (GSC) was measured using a ten-item scale developed by Zohar (2000). Example items are 'Whenever pressure builds up, my supervisor wants us to work faster, rather than by the safe work procedures' (reverse scored). All items were rated by respondents using a five-point Likert scale ranging from 5 (strongly agree) to 1 (strongly disagree).

In order to qualify for participation, organisations were required to be operating in the construction industry to be representative of construction firms and have a willingness to be involved in the study. Three organisations operating in the Australian construction industry agreed to participate in the survey. The three organisations were: $(a)$ the regional construction and maintenance works district of a state-based road construction and maintenance organisation in the south-east of Australia; (b) the Melbourne operations of a national steel reinforcement manufacturing organisation; and $(c)$ a hospital construction project, also in Melbourne. The data collected from these three organisations were combined in the analysis. The rationale for this was that, if the same patterns of relationships were found in three different organisations, the findings are arguably more applicable to the industry as a whole than would be evident if found in a single organisation of a specific type.

\subsection{Data analysis}

First, to determine whether unique and distinct group-level safety climates exist within the Australian construction industry (objective one), data were analysed to ascertain whether the two criteria listed here were satisfied.

(a) Between-group variation (i.e. whether safety climates differed significantly between workgroups within the same organisation)

(b) Within-group consensus (i.e. whether workers within a single group shared similar perceptions of the group safety climate).

Consistent with Zohar (2000), between-group differences in safety climate were explored by conducting a one-way analysis of variance (ANOVA). Within-group homogeneity of safety climate perceptions was examined by calculating the interrater agreement (IRA) (James et al., 1984).

Second, Pearson (bivariate) correlations were used to explore the relationship between perceptions of group level safety climate and the safety performance of workgroups included in the sample (objective two).

\section{Results}

4.1 The sample

A total of 307 surveys was received from the three organisations. The breakdown of respondents and workgroups is summarised in Table 1.

\subsection{Components of group safety climate}

The factor structure of the GSC was explored using a principal component's factor analysis (PCA). The results of the PCA 
Management, Procurement and Law Volume 166 issue MP6
Australian construction supervisors' response to occupational health and safety

Cooke, Lingard and Blismas

\begin{tabular}{lll}
\hline Organisation & $\begin{array}{l}\text { No. of } \\
\text { responses }\end{array}$ & $\begin{array}{l}\text { No. of } \\
\text { workgroups }\end{array}$
\end{tabular}

Road construction and maintenance organisation 71 15 Hospital construction project 99

\section{9}

National steel reinforcement 137 16 organisation

Table 1. Responses and workgroups by organisation

produced a two-factor structure that is consistent with Zohar's original conceptualisation of group safety climate (Zohar, 2000). Thus all but one of the GSC items loaded on one of two factors 'supervisors' safety actions' and 'supervisors' safety expectations.' The item that failed to load on either component of GSC was omitted from further analysis. 'Supervisors' safety actions' reflect workers' perceptions of supervisory reactions to subordinates' safety conduct (i.e. the supervisors' provision of positive or negative feedback to workers when particular safe or unsafe behaviours are observed). 'Supervisors' safety expectations' reflect workers' perceptions of their supervisors' safety-related expectations (i.e. the extent to which supervisors demand and expect workers to perform their work in a consistently safe manner). The internal consistency reliability of the two sub-scales was found to be satisfactory with Cronbach alpha scores of 0.80 and 0.71 , respectively.

\subsection{Study 1: Road construction and maintenance organisation}

Workgroups with fewer than three respondents were removed from the analysis, so as to protect anonymity of respondents and ensure that within-group consensus could be satisfactorily measured. As a result, eight responses were eliminated from the road construction and maintenance organisation sample, leaving 63 workers, representing 15 different workgroups, namely an average number of workers per group of 4.2. Mean scores for 'supervisors' safety actions' and supervisors' safety expectations' in each workgroup are shown in Figure 1.

The analysis of variance indicated that the assumption of homogeneity of variance in GSC was violated in the road construction and maintenance sample. Thus, to properly assess the extent to which there was significant variation in group safety climate scores between workgroups, reference had to be made to the adjusted Welch F-ratio (Howell, 2002). No significant between-group differences were found for perceptions of 'supervisors' safety actions' $(F=1.84, p=0.118)$. However,

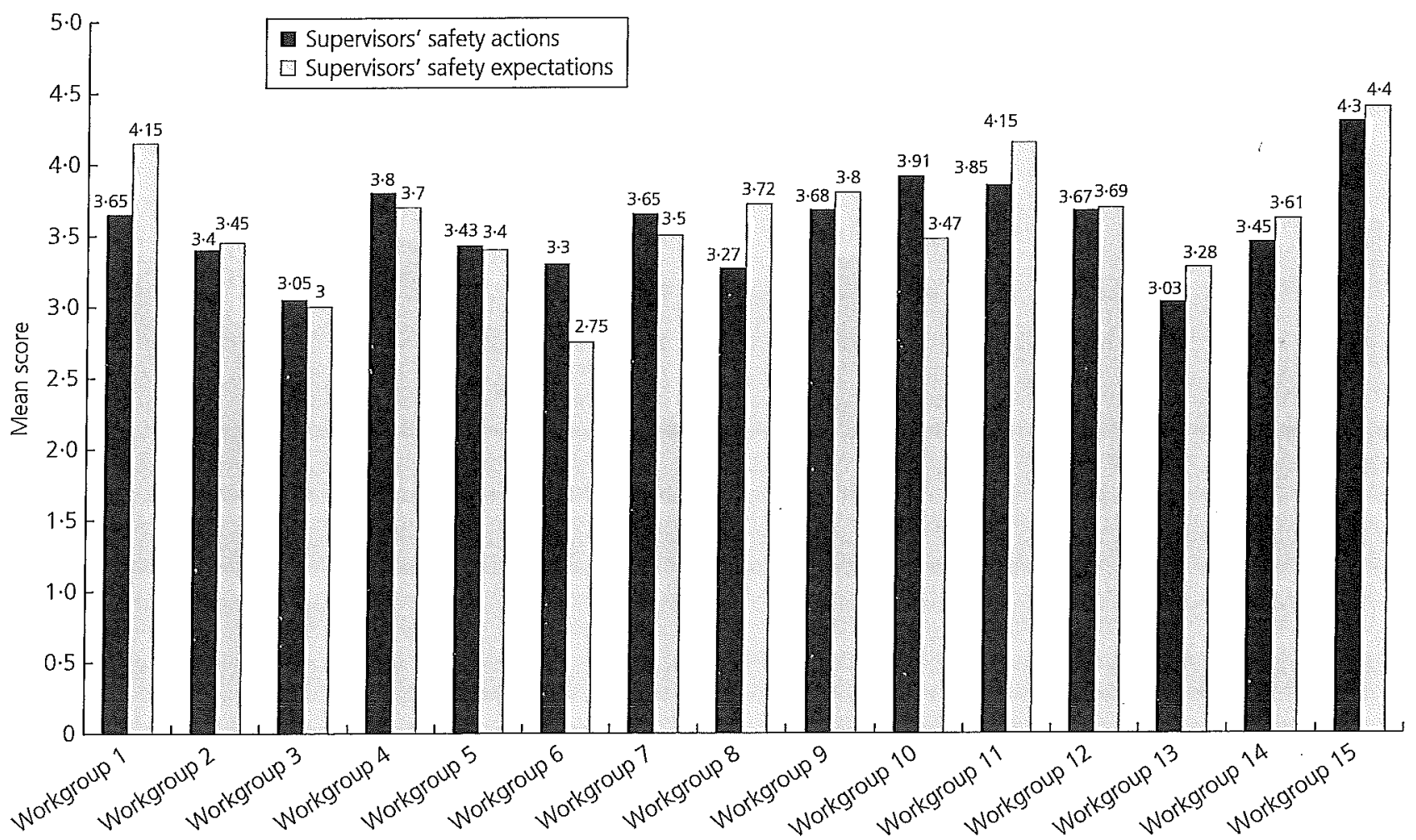

Figure 1. Supervisor's safety actions and expectations by workgroup at the road construction and maintenance organisation 
Management, Procurement and Law

Volume 166 Issue MP6
Australian construction supervisors' response to occupational health and

safety

Cooke, Lingard and Blismas significant between-group variation in perceptions of supervisors safety expectations' were evident $(F=3 \cdot 25, p=0.012)$.

The IRA results from the road construction and maintenance sample are presented in Table 2 . An acceptably high degree of within-group agreement $(r w g(j) \geq 70)$ concerning perceptions of 'supervisors' safety actions' was found for 13 of the 15 workgroups. Twelve of the 15 workgroups showed an acceptably high degree of within-group agreement regarding perceptions of 'supervisors' safety expectations'.

\subsection{Study 2: Hospital construction project}

As all nine workgroups at the hospital project returned more than three responses, no groups were excluded from the group-level analysis at this site. The average number of responses per workgroup was 11.0. Mean scores for 'supervisors' safety actions' and 'supervisors' safety expectations' in each workgroup are shown in Figure 2.

The ANOVA indicated significant between-group differences between workgroups regarding perceptions of 'supervisors' safety sctions' ( $F=5.75, p=0.001)$, and perceptions of 'supervisors' safety expectations' $(F=6.88, p=0.001)$ at the hospital construction project.

\begin{tabular}{lll}
\hline & $\begin{array}{l}\text { Supervisors' } \\
\text { safety action }\end{array}$ & $\begin{array}{l}\text { Supervisors' } \\
\text { safety expectation }\end{array}$ \\
\hline Workgroup 1 & 0.95 & 0.96 \\
Workgroup 2 & 0.94 & 0.86 \\
Workgroup 3 & 0.96 & 0.96 \\
Workgroup 4 & 0.96 & 0.94 \\
Workgroup 5 & 0.90 & 0.88 \\
Workgroup 6 & 0.00 & 0.00 \\
Workgroup 7 & 0.96 & 0.93 \\
Workgroup 8 & 0.00 & 0.00 \\
Workgroup 9 & 0.82 & 0.79 \\
Workgroup 10 & 0.94 & 0.96 \\
Workgroup 11 & 0.92 & 0.89 \\
Workgroup 12 & 0.96 & 0.90 \\
Workgroup 13 & 0.79 & 0.53 \\
Workgroup 14 & 0.96 & 0.96 \\
Workgroup 15 & 0.95 & 0.92
\end{tabular}

Table 2. Inter-rater agreement within workgroups at the road construction and maintenance organisation

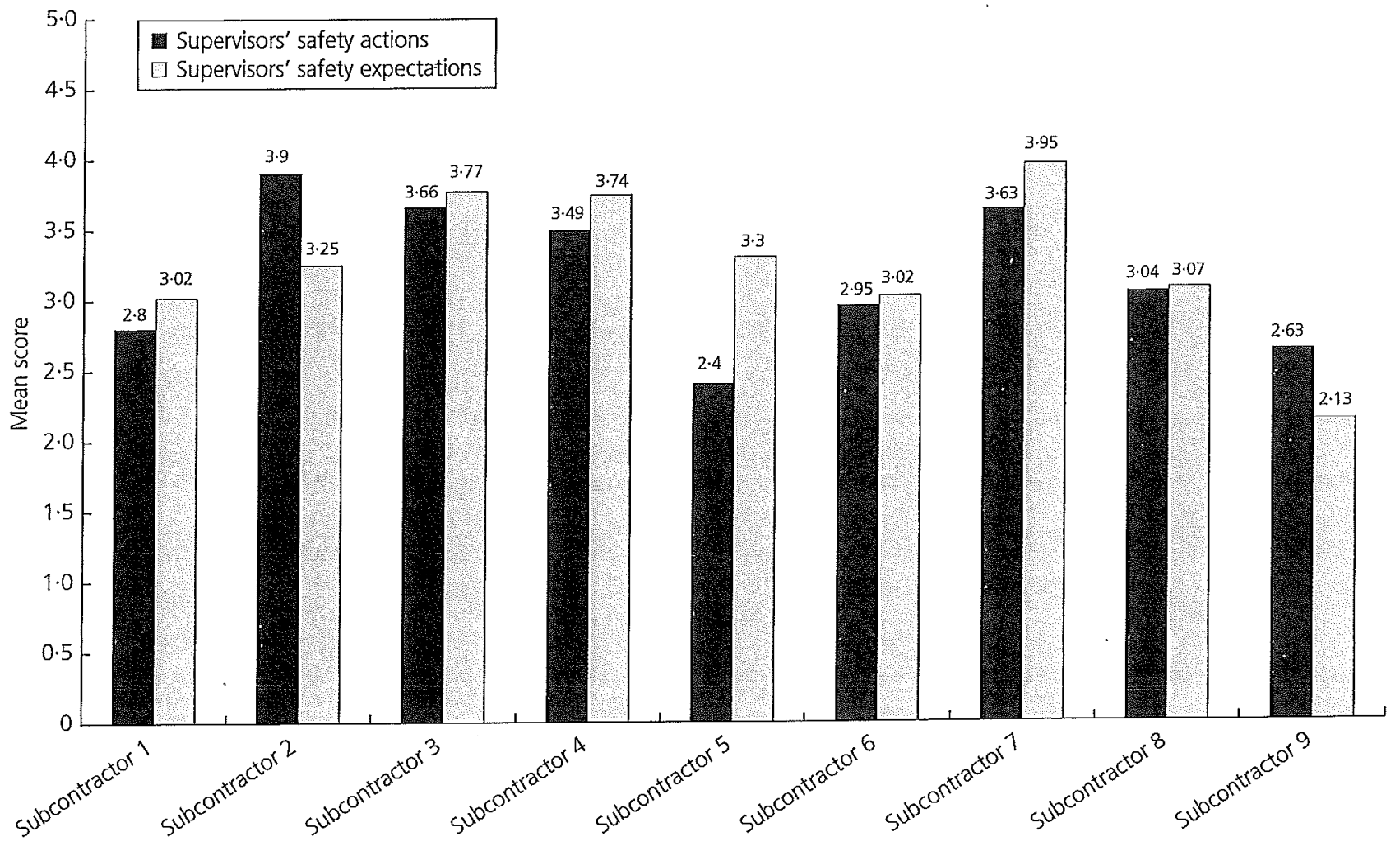

Figure 2. Supervisors' safety actions and expectations by subcontractor at the hospital construction project 
Management, Procurement and Law

Volume 166 issue MP6
Australian construction supervisors' response to occupational health and safety

Cooke, Lingard and Blismas
Further, the IRA scores were acceptably high for both 'supervisors' safety actions' and 'supervisors' safety expectations' for all but one of the nine workgroups at the hospital construction project (Table 3 ).

\subsection{Study 3: Steel reinforcement manufacturing organisation}

As all 16 workgroups at the steel reinforcement manufacturing organisation returned more than three responses, no groups were excluded from the group-level analysis in this organisation. Thus the average number of responses per workgroup was 8.6. Mean scores for 'supervisors' safety actions' and 'supervisors' safety expectations' in each workgroup are shown in Figure 3.

The assumption of homogeneity of variance in GSC was violated in the steel reinforcement manufacturing sample. Thus, reference had to be made to the adjusted Welch $F$-ratio. Significant between-group differences in perceptions of 'supervisors' safety actions' $(F=4.25, p=0.00)$ and 'supervisors' safety expectations' $(F=3.06, p=0.005)$ were found.

Further, the IRA scores were acceptably high for 'supervisors' safety actions' in all 16 workgroups (Figure 4). For 'supervisors' safety expectations' all but two of the workgroups at the steel

\begin{tabular}{lll}
\hline & $\begin{array}{l}\text { Supervisors' } \\
\text { safety action }\end{array}$ & $\begin{array}{l}\text { Supervisors' } \\
\text { safety expectation }\end{array}$ \\
\hline Subcontractor 1 & 0.79 & 0.85 \\
Subcontractor 2 & 0.99 & 0.81 \\
Subcontractor 3 & 0.94 & 0.98 \\
Subcontractor 4 & 0.97 & 0.95 \\
Subcontractor 5 & 0.00 & 0.00 \\
Subcontractor 6 & 0.83 & 0.83 \\
Subcontractor 7 & 0.94 & 0.94 \\
Subcontractor 8 & 0.73 & 0.79 \\
Subcontractor 9 & 0.71 & 0.88
\end{tabular}

Table 3. Inter-rater agreement within workgroups at the hospital construction project

reinforcement manufacturing facility demonstrated acceptably high IRA scores (Table 4).

\subsection{Supervisors' safery response and injury frequency rate}

Bivariate (Pearson) correlation analysis was performed to examine the relationship between perceptions of GSC and the

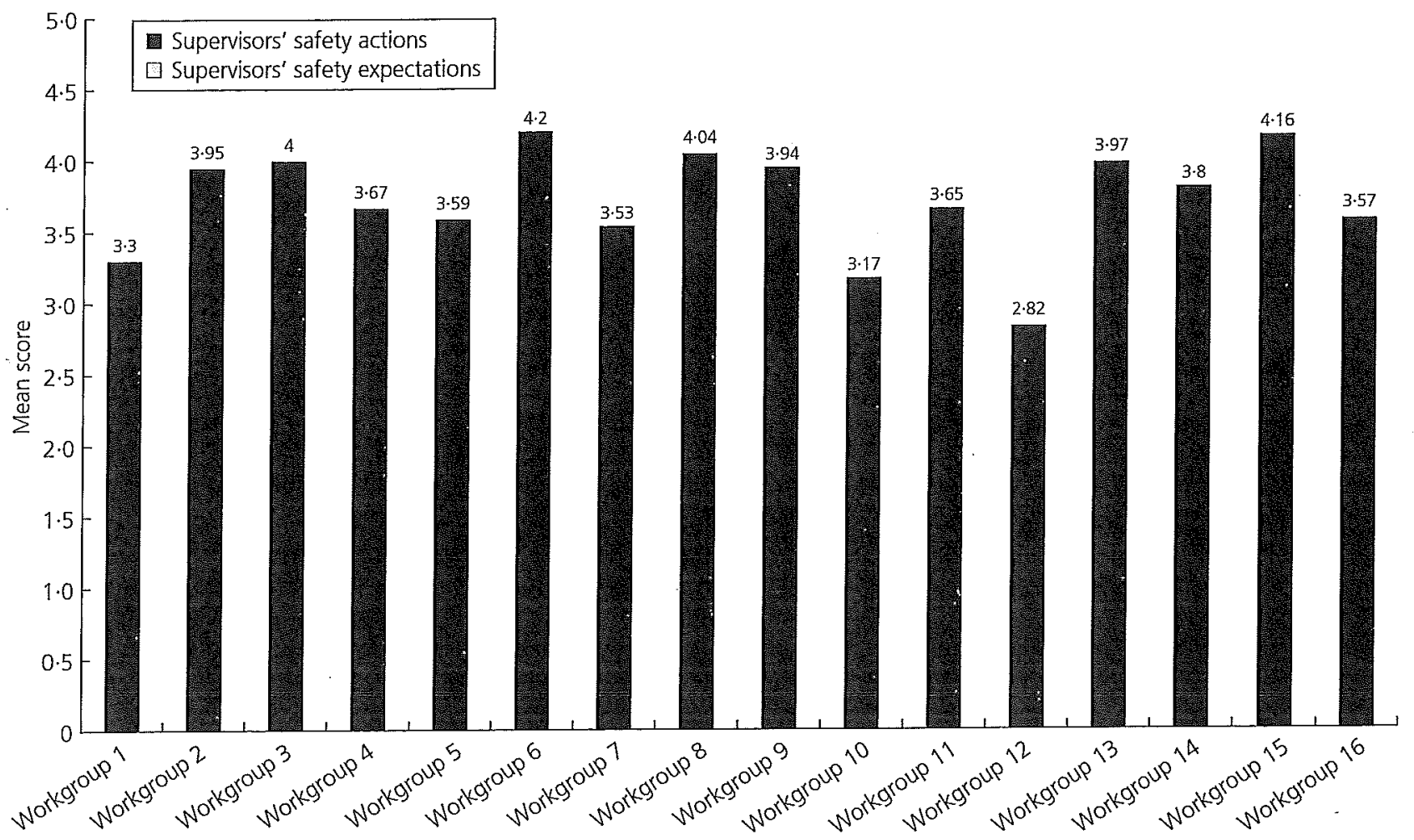

Figure 3. Supervisors' safety actions by workgroup at the steel reinforcement manufacturing organisation 


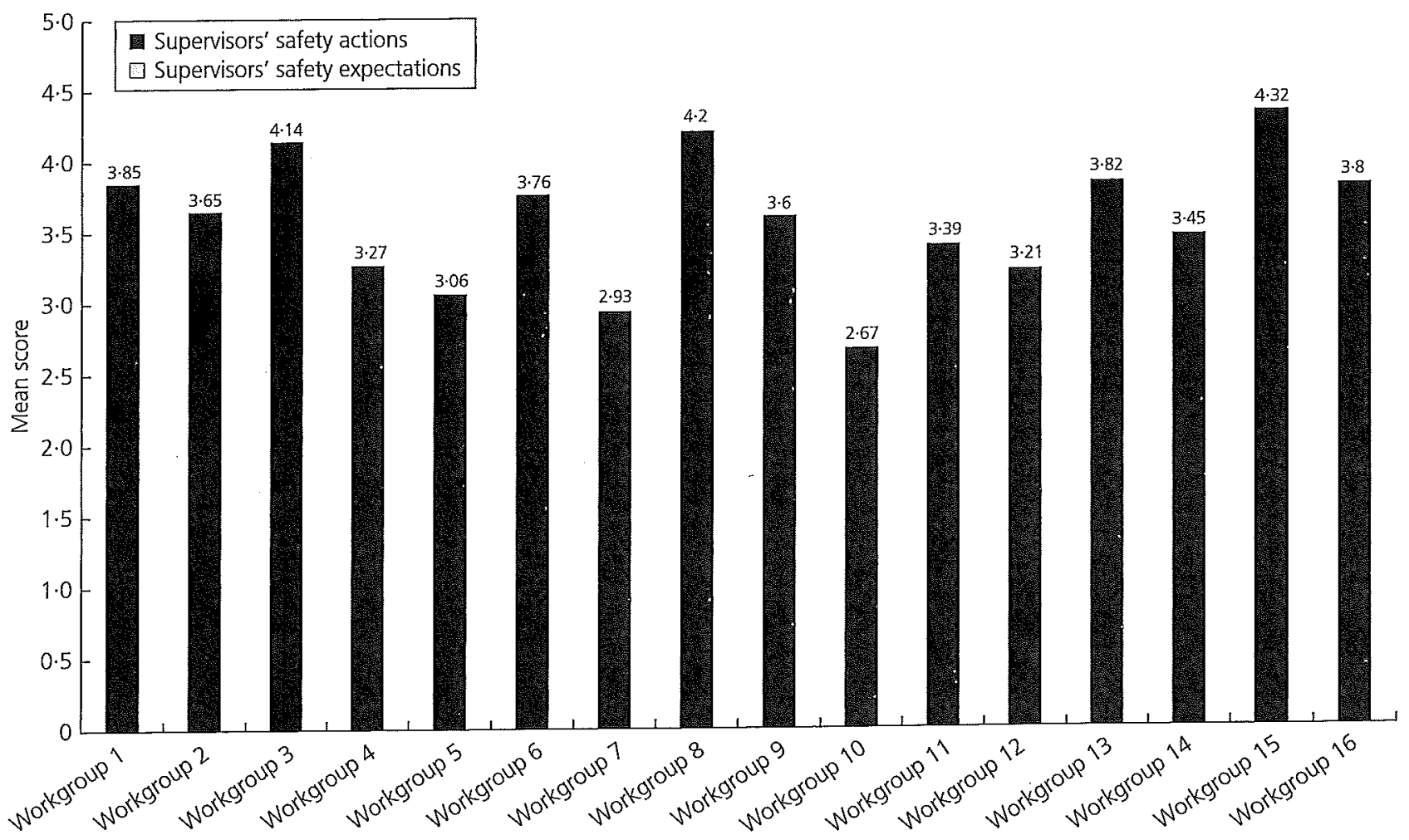

Figure 4. Supervisors' safety expectations by workgroup at the steel reinforcement manufacturing organisation

\begin{tabular}{lll}
\hline & $\begin{array}{l}\text { Supervisors' } \\
\text { safety action }\end{array}$ & $\begin{array}{l}\text { Supervisors' } \\
\text { safety expectation }\end{array}$ \\
\hline Workgroup 1 & 0.98 & 0.94 \\
Workgroup 2 & 0.91 & 0.38 \\
Workgroup 3 & 0.98 & 0.98 \\
Workgroup 4 & 0.99 & 0.90 \\
Workgroup 5 & 0.78 & 0.85 \\
Workgroup 6 & 0.98 & 0.93 \\
Workgroup 7 & 0.88 & 0.00 \\
Workgroup 8 & 0.92 & 0.93 \\
Workgroup 9 & 0.98 & 0.90 \\
Workgroup 10 & 0.91 & 0.89 \\
Workgroup 11 & 0.90 & 0.91 \\
Workgroup 12 & 0.75 & 0.83 \\
Workgroup 13 & 0.98 & 0.97 \\
Workgroup 14 & 0.90 & 0.91 \\
Workgroup 15 & 0.95 & 0.99 \\
Workgroup 16 & 0.91 & 0.95
\end{tabular}

Table 4. Inter-rater agreement within workgroups at the steel reinforcement manufacturing organisation injury/incident frequency rate of workgroups in the three organisational settings. The results of this analysis are presented in Table 5.

Retrospective injury data relate to the injury rate for a period of 12 months prior to the survey. Prospective data relate to the injury rate for a period after the survey was conducted. Unfortunately prospective injury data were not available for the road construction and maintenance or the steel reinforcement manufacturing organisations. A limited amount (4 months) of prospective injury data were available for the hospital construction project as the project was coming to an end and most subcontractors involved in the survey left the site 4 months after the survey.

At the road construction and maintenance organisation injury data could not be obtained at the workgroup level. The most fine-grained injury data available related to the work centre. A standard work centre consists of a number of work crews, with hierarchical reporting links via the team leader and works supervisor, then to the work centre manager. These data were used to test whether workers in groups with more favourable perceptions of the GSC were located within work centres with lower injury frequency rates. 


\begin{tabular}{|c|c|c|c|c|c|}
\hline & & \multicolumn{2}{|c|}{$\begin{array}{l}\text { Retrospective combined lost time and } \\
\text { medical treatment injury frequency rate }\end{array}$} & \multicolumn{2}{|c|}{$\begin{array}{l}\text { Prospective combined lost time and } \\
\text { medical treatment injury frequency rate }\end{array}$} \\
\hline & & $r$ & $p$ & $r$ & $p$ \\
\hline \multirow{2}{*}{$\begin{array}{l}\text { Road construction } \\
\text { and maintenance } \\
\text { organisation }\end{array}$} & $\begin{array}{l}\text { Supervisors' } \\
\text { safety actions }\end{array}$ & -0.126 & 0.377 & NA & NA \\
\hline & $\begin{array}{l}\text { Supervisors' } \\
\text { safety expectations }\end{array}$ & -0.219 & 0.122 & NA & NA \\
\hline \multirow[t]{2}{*}{$\begin{array}{l}\text { Hospital } \\
\text { construction project }\end{array}$} & $\begin{array}{l}\text { Supervisors' } \\
\text { safety actions }\end{array}$ & -0.151 & 0.155 & -0.111 & 0.492 \\
\hline & $\begin{array}{l}\text { Supervisors' } \\
\text { safety expectations }\end{array}$ & $-0.245^{*}$ & 0.020 & -0.150 & 0.350 \\
\hline \multirow{2}{*}{$\begin{array}{l}\text { National steel } \\
\text { reinforcement } \\
\text { organisation }\end{array}$} & $\begin{array}{l}\text { Supervisors' } \\
\text { safety actions }\end{array}$ & $0.309^{* *}$ & 0.003 & NA & $N A$ \\
\hline & $\begin{array}{l}\text { Supervisors' } \\
\text { safety expectations }\end{array}$ & $0.219^{*}$ & 0.037 & NA & NA \\
\hline
\end{tabular}

*Corralation significant at 0.05 level (two-tailed)

** Corralation significant at 0.01 level (two-tailed)

Table 5. Bivariate correlations between perceptions of supervisors' safety response and workgroup injury rates

The results show that in the road construction and maintenance organisation and at the hospital construction project, perceptions of the GSC were negatively correlated with retrospective injury rates. However, in most instances these correlations were not statistically significant. At the hospital construction project, perceptions of 'supervisors' safety expectations' were significantly inversely correlated with the retrospective injury rate $(r=-0.245, p=0.020)$

In the steel reinforcement organisation, perceptions of 'supervisors' safety actions' were significantly positively correlated with the retrospective injury frequency rate $(r=0.309$, $p=0.003$ ). Perceptions of supervisors' safety expectations were also significantly positively correlated with the injury frequency rate $(r=0.219, p=0.037)$.

No significant correlations were found between perceptions of the GSC and the prospective injury frequency rate at the hospital construction project.

\section{Discussion}

\subsection{Components of GSC}

Group safety climate (GSC) in construction comprises two components, namely 'supervisors' safety expectations' and 'supervisors' safety actions'. The clear factor loadings and absence of double loading indicate that these two facets are conceptually distinct. Further, the two-dimensional structure of the
GSC survey is consistent with Zohar's two-dimensional model of GSC (Zohar, 2000). This finding indicates that construction workers discriminate between perceptions of what a supervisor expects of them in relation to safe work behaviour and how the supervisor acts in relation to group members' safety-related behaviour. The bivariate correlations suggest that these two dimensions of GSC may be differentially related to group safety performance. It is therefore important to understand the supervisory behaviours that contribute to workers' perceptions of 'supervisors' safety expectations' and 'supervisors' safety actions' in the construction context, as well as the impact that these two components of GSC have on grouplevel safety performance. In particular, leadership training and development for first-level supervisors could be tailored to developing strong and positive perceptions of both supervisory actions and expectations in relation to safety. It is also important to ensure that actions and expectations conveyed to group members are consistent; that is, supervisors' statements about what is expected are consistent with feedback given when safe or unsafe behaviour is observed.

\subsection{Supervisor's' safety response as a facet of group-level safety climate}

With respect to the second research objective, the results were generally supportive of supervisors' safety response as a facet of group-level safety climate in the Australian construction industry. In order to conclude that group safety climates exist, the following two conditions must be satisfied (Zohar, 2000). 
(a) Between-group variance (i.e. whether safety climates differ significantly between workgroups within the same organisation).

(b) Within-group homogeneity (i.e. whether workers within a workgroup share similar perceptions of the safety climate).

In relation to 'supervisors' safety expectations', significant between-group differences were found in all three of the studies, satisfying the first of Zohar's criteria. Also, in relation to 'supervisors' safety expectations', the majority of workgroups in the analysis demonstrated high levels of IRA between group members. The IRA scores were above the threshold values for $800 \%$ of workgroups in the road construction and maintenance organisation, $88.9 \%$ of workgroups at the hospital construction project and $87.5 \%$ of workgroups at the steel reinforcement manufacturing organisation, providing strong support for within-group homogeneity in relation to perceptions of 'supervisors' safety expectations'; that is, largely satisfying Zohar's second criterion.

In relation to 'supervisors' safety actions', in two of the three studies (the hospital construction project and the steel reinforcement manufacturing organisation), both of the requisite conditions for the existence of group safety climate were met for 'supervisors' safety actions'. In other words, there was significant between-group variation and the majority of workgroups demonstrated high IRA scores - that is, $88.9 \%$ of workgroups at the hospital construction project and $100 \%$ of workgroups at the steel reinforcement manufacturing organisation indicated IRA scores above the 0.70 threshold. Thus, in relation to 'supervisors' safety actions', the requisite conditions for GSC were met in two of the three organisations.

However, although $86.7 \%$ of workgroups at the road construction and maintenance organisation demonstrated high levels of within-group homogeneity with regard to perceptions of 'supervisors' safety actions', no significant between-group differences were found at the road construction and maintenance organisation for this facet of supervisors' safety response. This indicates that perceptions of 'supervisors' safety actions' were not a facet of group-level safety climate at the road construction and maintenance organisation.

\subsection{Group safety climate and injury frequency rate}

The safety values and behaviours of supervisors are influential in shaping the safety values and behaviours of their subordinates (Maierhofer et al., 2000). Supervisors act as powerful role models exercising substantial influence upon their subordinates. When supervisors clearly and explicitly annunciate their strong safety values and reinforce these values with consistent behaviour, subordinates are likely to take on similar values. The implication of these findings is that supervisors' safety responses, as perceived by members of their workgroups, are likely to play an important part in shaping safety outcomes.

The data collected in the present study showed an inconsistent pattern of relationships between perceptions of supervisors' safety response and workgroup safety performance.

In the road construction and maintenance organisation and at the hospital construction project, 'supervisors' safety actions' and 'supervisors' safety expectations' were inversely related to the combined injury frequency rates of workgroups, but this relationship was only statistically significant in relation to perceptions of 'supervisors' safety expectations' at the hospital construction project. The direction of the observed correlations at the road construction and maintenance organisation and hospital construction project was as expected, indicating that workgroups with stronger and more positive group safety climates have better injury rates.

Also, the relationship between 'supervisors' safety expectations' and the combined lost time and medical treatment injury rate was only significant in the case of retrospective safety performance data at the hospital construction project. When considering retrospective injury data, both facets of the GSC were significantly correlated with workgroup injury rates in the steel reinforcement manufacturing organisation but the relationship was in the opposite direction to that expected, namely the correlation was positive. It is possible that the past experience of injuries within a workgroup could increase supervisors' safety expectations and actions in the future. This reflects a reverse causation effect whereby poor safety performance may lead to interventions to improve supervisors' safety performance, resulting in improved perceptions of the GSC at a future point in time. Unfortunately the cross-sectional nature of this research precluded any analysis of the direction of causation in the safety climate-performance relationship. Further longitudinal research is recommended to examine the possibility of reverse causation.

The inconsistent pattern of relationships between workgroup injury rates and perceptions of supervisors' safety response may be due to the fact that lost time and medical treatment injury rates are not a sufficiently sensitive measure of safety performance to reflect changes in safety performance at a workgroup level. Reportable injuries are statistically rare events and may not be a useful measure of subtle changes in safety performance at the level of the workgroup. Further research should be conducted to examine the relationship between supervisors' safety response and injury rates using a more fine-grained measure of workgroup safety performance, such as micro-accidents or minor (non-reportable) injuries (Zohar, 2000). 
However, there are also other theoretically possible reasons for the failure to find a direct correlation between perceptions of supervisors' safety response and workgroups' prospective injury rates, which also warrant further investigation. For example, it is possible that the relationship between the GSC and workgroup safety performance is moderated by other factors, such as the quality of relationships between supervisors and their subordinates. Thus, if workers do not perceive that they have a good relationship with their supervisor and/or they have little interest in maintaining a quality relationship, then the link between supervisors' safety response and workgroup safety performance will be disrupted. Previous research has linked the quality of relationships between supervisors and subordinates with safety outcomes: For example, Hofmann and Morgeson (1999) report that group leaders who have highquality relationships with their own supervisors are more likely to feel free to raise safety concerns. This safety-related communication, in turn, is related to safety commitment and improved safety performance in the workgroups they lead.

\subsection{Implications for practice}

The findings have implications for organisations interested in the development of strong and supportive safety climates at all levels within their operations. In order to develop safetysupportive climates within workgroups, it is critical that supervisors are consistent in the way that they emphasise (or de-emphasise) OHS in their interactions with employees. Climates are formed on the basis of the day-to-day interactions and observations of supervisors' behaviour. Over time, supervisors' behaviour is observed to form a pattern. Positive and strong safety climates will develop only to the extent that supervisors are consistent in what they say and do in relation to safety. Thus, similar events or situations should elicit similar safety responses from supervisors, reflecting stability in the importance placed upon safety relative to other project objectives, such as time, cost or quality. Where the supervisors' safety responses are perceived to be contingent upon the circumstances, for example if supervisors change their behaviour when facing more intense production pressure, the resulting safety climate will be weak (Zohar and Luria, 2004). Thus, interventions to support the development of supervisory safety leadership are likely to promote positive perceptions of 'supervisors' safety expectations' and 'supervisors' safety actions' within construction workgroups.

\section{Conclusion}

The results provide preliminary evidence that perceptions of supervisors' safety response should be considered a dimension of group-level safety climate in the construction industry. It is important that safety climate researchers do not confound organisation-level climates with workgroup-level climates because this research has confirmed that workgroups develop their own distinct safety climates driven by perceptions of first-level supervisors' safety response. The influential role of supervisors is likely to be particularly important in the construction sector in which work is non-repetitive and performed by semi-autonomous work crews at locations remote from the organisation's corporate offices. In this context, the discretionary influence of first-level supervisors is likely to be considerable, relative to the influence of senior management and/or specialist safety personnel responsible for the development of organisational safety policy and procedures.

The existence of distinct workgroup safety climates also suggests that supervisors are an important conduit through which top management support for safety is translated to workgroup priorities. This begins to explain why some organisational workgroups consistently perform better in OHS than others (despite having very similar risk exposures), and suggests that interventions designed to develop supervisors' safety leadership capabilities may yield significant improvements for group-level safety climates, thus positively impacting safety performance.

\subsection{Limitations and future research}

The research was limited by the reliance upon retrospective lost time and medical treatment injury rates as the measure of workgroup safety performance. Future research, using prospective designs and more sensitive measures of workgroup safety performance, are needed.

\section{REFERENCES}

Clarke S (2006) The relationship between safety climate and safety performance: a meta-analytic review. Journal of Occupational Health Psychology 11(4): 315-327.

Hofmann DA and Morgeson FP (1999) Safety-related behavior as a social exchange: the role of perceived organizational support and leader-member exchange. Journal of Applied Psychology 84(2): 286-296.

Howell DC (2002) Statistical Methods for Psychology, 5th edn. Wadsworth, Pacific Grove, CA, USA.

James LR, Demaree RG and Wolf G (1984) Estimating withingroup interrater reliability with and without response bias. Journal of Applied Psychology 69(1): 85-98.

Johnson SE (2007) The predictive validity of safety climate. Journal of Safety Research 38(5): 511-521.

Leather PJ (1987) Safety and accidents in the construction industry: a work design perspective. Work and Stress 1(2): 167-174.

Lingard $\mathrm{H}$, Cooke T and Blismas N (2009) Group-level safety climate in the Australian construction industry: withingroup homogeneity and between-group differences in road construction and maintenance. Construction Management and Economics 27(4): 419432.

Maierhofer N, Griffen MA and Sheehan M (2000) Linking manager values and behaviour with employees values and behaviour: A study of values and safety in the hairdressing 
industry. Joumal of Occupational Health Psychology 5(4): 417-427.

Neal A and Griffin MA (2006) A study of the lagged relationships among safety climate, safety motivation, safety behaviour and accidents at individual and group levels. Journal of Applied Psychology 91(4): 946-953.

Niskanen T (1994) Assessing the safety environment in work organisation of road maintenance. Accident Analysis and Prevention 26(1): 27-39.

Pousette A, Larsson S and Törner M (2008) Safety climate cross-validation, strength and prediction of safety behaviour. Safety Science 46(3): 398-404.

Siu O, Phillips DR and Leung T (2004) Safety climate and safety performance among construction workers in Hong Kong: the role of psychological strains as mediators. Accident Analysis and Prevention 36(3): 359-366.
Zhou Q, Fang DP and Wang X (2008) A method to identify strategies for the improvement of human safety behavior by considering safety climate and personal experience. Safety Science 46(10): 1406-1419.

Zohar D (2000) A group-level model of safety climate: testing the effect of group climate on microaccidents in manufacturing jobs. Journal of Applied Psychology 85(4): 587-596.

Zohar D and Luria G (2004) Climate as a social-cognitive construction of supervisory safety practices: scripts as proxy of behavior patterns. Jounal of Applied Psychology 89(2): 322-333.

Zohar D and Luria G (2005) A multilevel model of safety climate: cross-level relationships between organization and group-level climates. Joumal of Applied Psychology 90(4): 616-628.

\section{WHAT DO YOU THINK?}

To discuss this paper, please email up to 500 words to the editor at journals@ice.org.uk. Your contribution will be forwarded to the author(s) for a reply and, if considered appropriate by the editorial panel, will be published as a discussion in a future issue of the journal.

Proceedings journals rely entirely on contributions sent in by civil engineering professionals, academics and students. Papers should be 2000-5000 words long (briefing papers should be 1000-2000 words long), with adequate illustrations and references. You can submit your paper online via www.icevirtuallibrary.com/content/journals, where you will also find detailed author guidelines. 